\title{
Optimal Microimplant Sites in the Mandibular Retromolar Area: Mesh Analysis of Cortical Bone Thickness and Density in CBCT Images
}

\author{
Sitios de Microimplantes Óptimos en el Área Retromolar Mandibular: \\ Análisis de Malla del Grosor y Densidad del Hueso Cortical en Imágenes CBCT
}

Sen Wang' ${ }^{1}$ Li Bing ${ }^{2}$ \& Hyo-Sang Park ${ }^{1}$

\begin{abstract}
WANG, S.; BING, L. \& PARK, H. S. Optimal microimplant sites in the mandibular retromolar area: Mesh analysis of cortical bone thickness and density in CBCT images. Int. J. Morphol., 39(3):907-914, 2021.

SUMMARY: This study was performed to identify optimal microimplant sites in the mandibular retromolar area by measurement and analysis of cortical bone thickness and density. Forty-nine records of cone-beam computed tomography were selected from 173 patients. Invivo 5.2 software was used to measure the thickness and density of 25 sites on a mesh in the mandibular retromolar area. Pearson correlation, Spearman correlation, and binary logistic regression analyses were performed to explore correlations between retromolar measurements and patient characteristics. The LSD test was used to identify optimal microimplant sites in this area. One-way ANOVA, with post hoc SNK test, was used to compare optimal microimplant sites among the retromolar area, the distobuccal bone of the second molar, and a location between the first and second molars. The mean thickness and density of mandibular retromolar cortical bone were $2.35 \pm 0.76 \mathrm{~mm}$ and $530.49 \pm 188.83 \mathrm{HU}$, respectively. In the mandibular retromolar area, the thickness and density of cortical bone increased from the lingual to buccal sides, and from the distal to mesial. Among 25 sites, S5C1 had the greatest thickness and density; it exhibited greater thickness and density, compared with the distobuccal bone of the second molar and the site between the first and second molars. For distal uprighting of mesially tipped molars, we recommend placement of microimplants into the retromolar distobuccal site; for distalization of mandibular dentition, we recommend placement of microimplants into the retromolar mesiobuccal site ( $\mathrm{S} 5 \mathrm{C} 1$ ) or $2 \mathrm{~mm}$ from the mesial direction of the second molar distobuccal site (B).
\end{abstract}

KEY WORDS: Retromolar; Microimplant sites; Thickness; Density; Mesh analysis.

\section{INTRODUCTION}

Microimplants are widely applied in orthodontic treatment, such as eruption of impacted canines (Park \& Oh, 2010), intrusion (Yao et al., 2004) or uprighting (Park et al., 2004) of molars, retraction of anterior teeth (Aljhani \& Zawawi, 2010), treatment of skeletal Class I bialveolar protrusion (Upadhyay et al., 2008), treatment of Class II deep bite (Park et al., 2011) distalization of maxillary dentition to correct Class II malocclusion (Bechtold et al., 2013), and distalization of mandibular dentition to correct Class III malocclusion (Chung et al., 2010). The advantages of microimplants, such as low cost, immediate loading, ease of placement and removal, and small size that allows placement in alveolar bone (Park, 2015) have led to expansion of their use.
To achieve microimplant stability, adequate bone thickness and density are needed (Park \& Cho, 2009). Several previous studies have evaluated the thickness of alveolar bone with cone-beam computed tomography (CBCT), and they showed that cortical bone was thicker in adult patients (Farnsworth et al., 2011), as well as those with hypodivergence (Horner et al., 2012) and low angle (Ozdemir et al., 2013).

For distalization of lower dentition, there are three positions for microimplants: the alveolar bone between first and second molars, distobuccal bone to second molar, and retromolar area (Park, 2015). For safe microimplant placement, the mandibular retromolar area exhibits adequate bone thickness and density (Park et al., 2008); it also does

\footnotetext{
${ }^{1}$ Department of Orthodontics, School of Dentistry, Kyungpook National University, Daegu, Korea.

${ }^{2}$ Department of Orthodontics, School of Dentistry, Shanxi Medical University, Taiyuan, China.
} 
not carry a risk of root damage. Thus, the mandibular retromolar area is a suitable microimplant site for distal uprighting of mesially tipped molars (Park et al., 2004) and distalization of lower dentition (Poletti et al., 2013). Because the force directions during the treatment are different according to placement sites, different site can be chosen for each treatment. Therefore, the understanding of bone quality and quantity on each site might be utmost important.

To the best of our knowledge, there have been few studies regarding cortical bone thickness and density at sites in the mandibular retromolar area. Accordingly, this study was performed to measure the thickness and density of mandibular retromolar cortical bone at various sites by using CBCT images; it also explored correlations between retromolar measurements and patient characteristics, and then identified optimal microimplant sites in these areas.

\section{MATERIAL AND METHOD}

The Institutional Review Board of the Kyungpook National University Dental Hospital approved the study. For this retrospective study, CBCT records were screened for 173 Korean patients who had visited the Kyungpook National University Dental Hospital (Daegu, Korea) during the period from November 4, 2010 to October 10, 2018. CBCT records were included if they met the following criteria: first and second mandibular molars were intact; no dental implants were present; and the patients had no history of orthognathic surgery or diseases affecting cortical bone thickness and density. CBCT records were excluded, if the mandibular retromolar area could not accommodate a square mesh of $64 \mathrm{~mm}^{2}$ in the "Axial 3D Volume Clipping" mode; cortical bone discontinuity and shadows were present in the mandibular retromolar area; and/or third molars had been extracted within the previous 6 months. Following application of these criteria, the CBCT records of 49 patients ( 31 men and 18 women) were included in this study; of these 49 patients, 19 and 30 had and did not have third molars, respectively, while 15 , four, and 30 had skeletal Class I, Class II, and Class III malocclusion, respectively. The average patient age, the average SN-GoGn angle and the average mandibular retromolar area are shown in Table I, as determined using the "Axial 3D Volume Clipping" mode in CBCT images.

Table I Patient characteristics.

\begin{tabular}{lcc}
\hline & Mean & Std. Deviation \\
\hline Ages & 24.53 & 5.30 \\
SN-GoGn $\left(^{\circ}\right)$ & 34.06 & 6.57 \\
Area $\left(\mathrm{mm}^{2}\right)$ & 192.01 & 26.23 \\
\hline
\end{tabular}

Instruments and software. CBCT images were acquired using an X-ray scanner, with the settings $15 \mathrm{~mA}$ and 120 kV (CB MercuRay, Hitachi Medical Corporation, Tokyo, Japan). The measurement method was "cone beam 360," scan time was 10 seconds, and slice thickness was $2 \mathrm{~mm}$. The resulting CBCT data were analyzed using Invivo software (Version 5.2, Anatomage, San Jose, CA, U.S.A.) for measurement of cortical bone thickness $(\mathrm{mm})$ and density (HU).

Measurement sites. Five parallel sagittal lines (S lines) were drawn with $2 \mathrm{~mm}$ interval from the disto-buccal side of the second molar (Fig. 1). Five parallel coronal lines (C lines) were drawn at $2 \mathrm{~mm}$ interval from the distal surface of the second molar on coronal slices of CBCT images (Fig. 1). In this manner, an 8-mm-wide (64 square millimeters) square mesh was formed in the mandibular retromolar area, with five measurement sites on each line. Hence, 25 microimplant sites were measured on the " $\mathrm{S}$ " C mesh." And cortical bone thickness and density were measured at site C ( $2 \mathrm{~mm}$ buccal on distal surface line of the second molar), and site B ( $2 \mathrm{~mm}$ mesial to site $\mathrm{C}$ ), and site A (site between first and second molars, $5 \mathrm{~mm}$ below the alveolar crest).

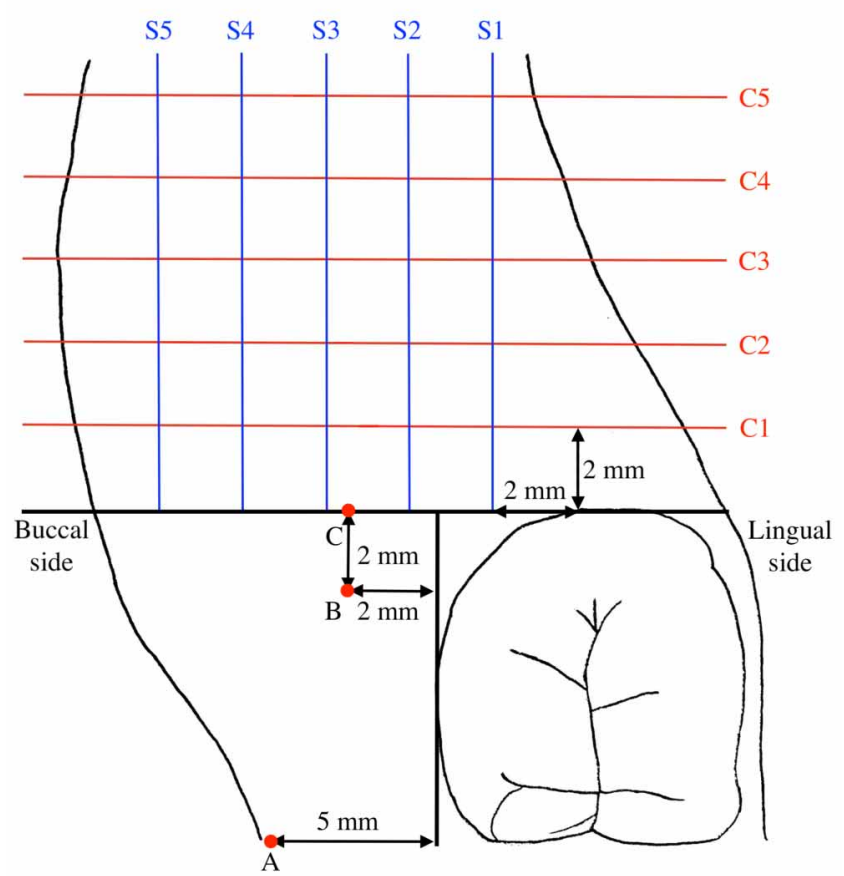

Fig. 1 Five parallel sagittal lines (S1-S5) intersect five parallel coronal lines $(\mathrm{C} 1-\mathrm{C} 5)$ in the mandibular retromolar area with a 2 $\mathrm{mm}$ interval; Site C, $2 \mathrm{~mm}$ buccal from the buccal surface on distal surface line of the second molar; Site B, $2 \mathrm{~mm}$ mesial to site C; Site A, site between the first and second molars, $5 \mathrm{~mm}$ below the alveolar crest. 
Statistical analysis. IBM SPSS Statistics, version 21.0 (IBM Corp. Armonk, NY, USA) was used for statistical analysis. The Shapiro-Wilk test was used to analyze the normality of the data; notably, all data demonstrated a normal distribution. Pearson and Spearman correlation analyses, as well as binary logistic regression analysis, were performed to assess correlations between mandibular retromolar measurements and patient characteristics. The twenty-five microimplant sites in the mandibular retromolar area are located at 2-mm intervals from each other. Hence, for mean comparisons among 25 sites on the "S ' C mesh," the Least Significant Difference (LSD) test was used. One-way ANOVA, with post hoc SNK test, was used to compare the optimal microimplant sites among the retromolar area, and site $\mathrm{A}, \mathrm{B}$, and $\mathrm{C}$. To calculate thickness and density measurement errors, 49 measurement sites were randomly selected and remeasured one month later, then compared using the paired t-test $(\mathrm{P}<.05)$ and Dahlberg's formula (Dahlberg, 1940), respectively. Paired t-tests showed there were no significant differences between thickness and density measurements. Dahlberg's formula (Dahlberg) of thickness and density measurements revealed method errors of 0.60 and 76.94 , respectively.

\section{RESULTS}

Correlation between retromolar measurements and characteristics of 49 patients. Spearman correlation analysis revealed a significant relationship between the cortical bone thickness of the mandibular retromolar area and the presence of a third molar $(\mathrm{P}<.01$; Table II). To further assess this correlation, binary logistic regression analysis was applied. As shown in Table III, the cortical bone thickness of the mandibular retromolar area was thicker in patients with a third molar than in patients without a third molar.

Cortical bone thickness in retromolar area. The mean thickness of mandibular retromolar cortical bone was 2.35 $\pm 0.76 \mathrm{~mm}$; site S5C1 $(3.57 \pm 0.61 \mathrm{~mm})$ exhibited the greatest cortical bone thickness among the 25 sites (Figs. 2 and 4). Moreover, the LSD test revealed a significant difference between site S5C1 and the remaining 24 sites (Table IV; all $\mathrm{P}<.0001)$. The cortical bone thickness increased from the lingual side to the buccal side, as well as from the distal side to the mesial side (Figs. 2 and 4).

Table II Correlations between retromolar measurements and patient demographics.

\begin{tabular}{lcccc}
\hline & \multicolumn{2}{c}{ Thickness $(\mathrm{mm})$} & \multicolumn{2}{c}{ Density (HU) } \\
\cline { 2 - 5 } & $\begin{array}{l}\text { Correlation } \\
\text { coefficient }\end{array}$ & Sig. & $\begin{array}{l}\text { Correlation } \\
\text { coefficient }\end{array}$ & Sig. \\
\hline Sex & -0.213 & 0.143 & 0.135 & 0.356 \\
Age & -0.195 & 0.180 & -0.137 & 0.348 \\
Skeletal class & 0.265 & 0.065 & -0.065 & 0.659 \\
SN-GoGn $\left({ }^{\circ}\right)$ & 0.055 & 0.706 & 0.091 & 0.534 \\
Third molar presence & $0.480^{* *}$ & 0.000 & 0.222 & 0.125 \\
Left or right & 0.218 & 0.133 & 0.142 & 0.330 \\
Thickness $(\mathrm{mm})$ & & & 0.246 & 0.089 \\
Density $(\mathrm{HU})$ & 0.246 & 0.089 & & \\
\hline
\end{tabular}

**. $\mathrm{P}<.01$ (two-tailed).

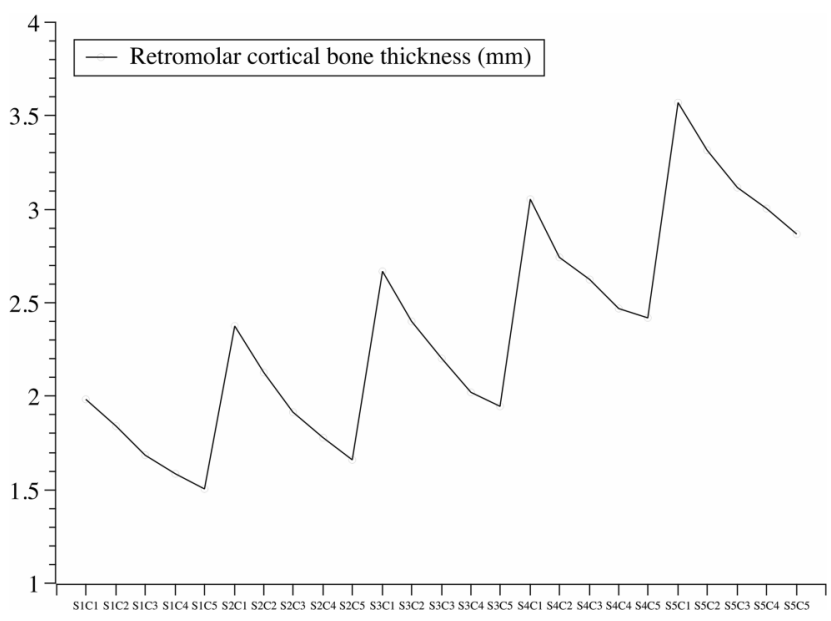

Fig. 2 Mean cortical bone thicknesses of 25 microimplant sites in the mandibular retromolar area.

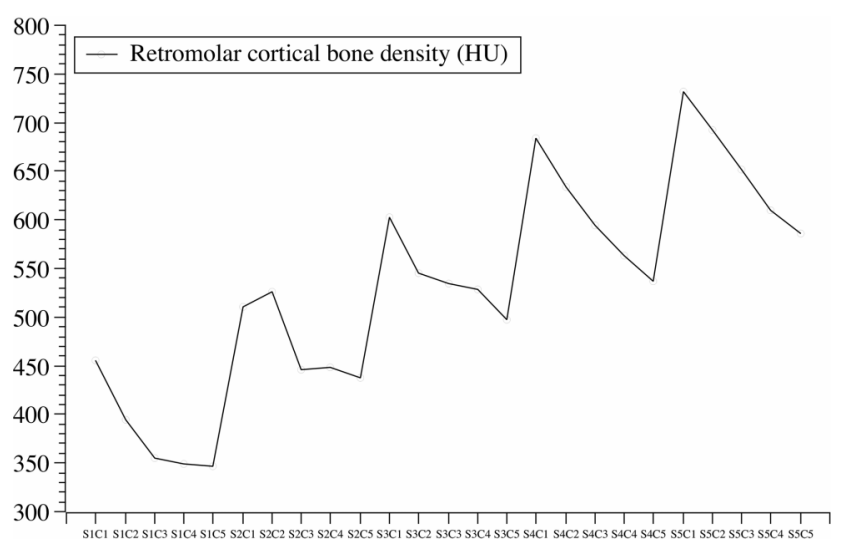

Fig. 3 Mean cortical bone densities of 25 microimplant sites in the mandibular retromolar area. 
WANG, S.; BING, L. \& PARK, H. S. Optimal microimplant sites in the mandibular retromolar area: Mesh analysis of cortical bone thickness and density in CBCT images. Int. J. Morphol., 39(3):907-914, 2021.

Table III Binary logic regression analyses of cortical bone thickness and third molar presence.

\begin{tabular}{llcccccc}
\hline & & B & S.E, & Wals & df & Sig. & Exp (B) \\
\cline { 3 - 8 } Step 1a & Thickness (mm) & 3.238 & 1.060 & 9.337 & 1 & 0.002 & 25.482 \\
& Constant & -8.197 & 2.577 & 10.118 & 1 & 0.001 & 0.000 \\
\hline
\end{tabular}

a. Variable entered in step 1: thickness.

Cortical bone density in retromolar area. The mean density of mandibular retromolar cortical bone was $530.49 \pm 188.83 \mathrm{HU}$; site S5C1 (731.96 $\pm 144.36 \mathrm{HU})$ exhibited the greatest cortical bone density among the 25 sites (Figs. 3 and 4). Moreover, the LSD test revealed a significant difference between site $\mathrm{S} 5 \mathrm{C} 1$ and the remaining 24 sites (Table V; all $\mathrm{P}<.0001$; $22 \mathrm{~S} 2, \mathrm{P}=$ 0.002). The cortical bone density increased from the lingual side to the buccal side, as well as from the distal side to the mesial side, with the exception of five measurement sites on the S2 line (Figs. 3 and 4).

Comparison of thickness and density of S5C1, C, B and $A$ sites in the mandible. Differences in thickness and density were compared among the retromolar mesiobuccal site (S5C1), and site A, B, C. Statistical analyses were performed with the SNK test. The cortical bone thickness and density of site $\mathrm{C}$ were $2.37 \pm 0.86$ $\mathrm{mm}$ and $453 \pm 115 \mathrm{HU}$, respectively; cortical bone thickness and density of site B were $2.81 \pm 1.01 \mathrm{~mm}$ and $511 \pm 106 \mathrm{HU}$, respectively; and cortical bone

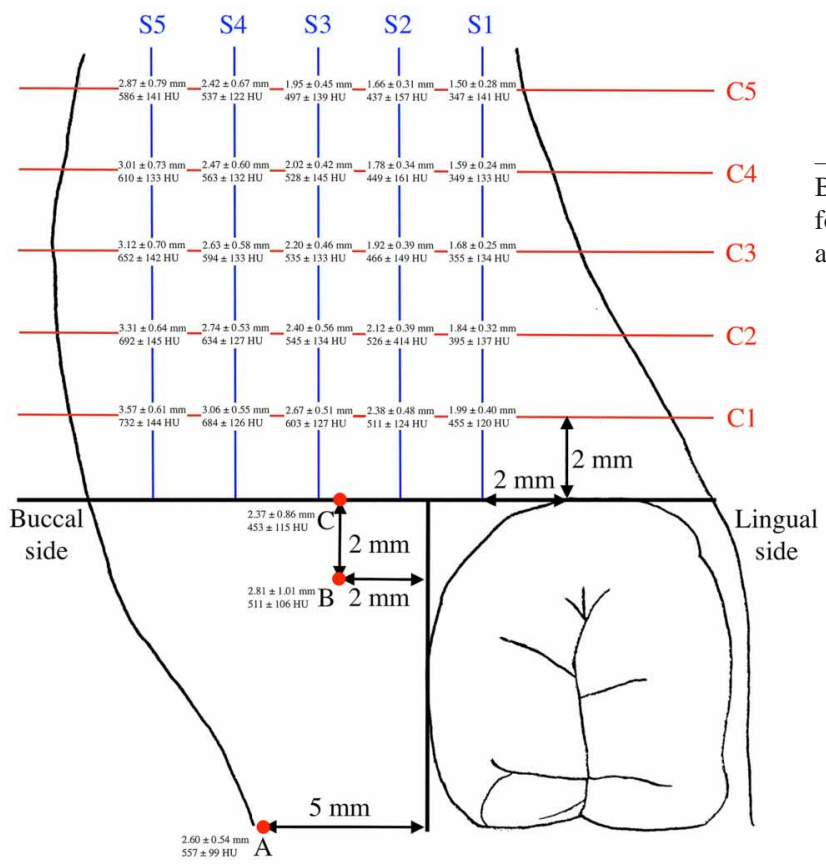

Fig. 4. Cortical bone thicknesses and densities of sites A, B and C, and 25 microimplant sites in the mandibular retromolar area.
Table IV Multiple comparisons of cortical bone thickness in retromolar area.

\begin{tabular}{llccc}
\hline (I) $\mathrm{z}$ & (J) $\mathrm{z}$ & \multicolumn{3}{c}{ Thickness (mm) } \\
\cline { 3 - 5 } & & Mean Difference (I-J) & Std. Error & Sig. \\
\hline \multirow{2}{*}{ S5C1 } & S1C1 & $1.586^{*}$ & 0.093 & $<.0001$ \\
& S1C2 & $1.731^{*}$ & 0.089 & $<.0001$ \\
& S1C3 & $1.886^{*}$ & 0.088 & $<.0001$ \\
& S1C4 & $1.985^{*}$ & 0.094 & $<.0001$ \\
& S1C5 & $2.067^{*}$ & 0.093 & $<.0001$ \\
& S2C1 & $1.194^{*}$ & 0.079 & $<.0001$ \\
& S2C2 & $1.447^{*}$ & 0.083 & $<.0001$ \\
S2C3 & $1.654^{*}$ & 0.084 & $<.0001$ \\
& S2C4 & $1.795^{*}$ & 0.083 & $<.0001$ \\
& S2C5 & $1.910^{*}$ & 0.080 & $<.0001$ \\
S3C1 & $0.901^{*}$ & 0.074 & $<.0001$ \\
S3C2 & $1.172^{*}$ & 0.078 & $<.0001$ \\
S3C3 & $1.371^{*}$ & 0.073 & $<.0001$ \\
S3C4 & $1.552^{*}$ & 0.073 & $<.0001$ \\
S3C5 & $1.622^{*}$ & 0.085 & $<.0001$ \\
S4C1 & $0.513^{*}$ & 0.056 & $<.0001$ \\
S4C2 & $0.826^{*}$ & 0.069 & $<.0001$ \\
S4C3 & $0.944^{*}$ & 0.059 & $<.0001$ \\
S4C4 & $1.104^{*}$ & 0.067 & $<.0001$ \\
S4C5 & $1.153^{*}$ & 0.082 & $<.0001$ \\
S5C2 & $0.256^{*}$ & 0.032 & $<.0001$ \\
S5C3 & $0.452^{*}$ & 0.048 & $<.0001$ \\
S5C4 & $0.565^{*}$ & 0.058 & $<.0001$ \\
S5C5 & $0.704^{*}$ & 0.077 & $<.0001$ \\
\hline
\end{tabular}

Based on estimated marginal means *. $\mathrm{P}<.05$ for mean difference. c. Adjustment for multiple comparisons: Least Significant Difference test (equivalent to no adjustments).

thickness and density of site A were $2.60 \pm 0.54 \mathrm{~mm}$ and $557 \pm 99 \mathrm{HU}$, respectively (all shown in Fig. 4). Cortical bone thickness and density were significantly greater at site $\mathrm{S} 5 \mathrm{C} 1$ than at sites $\mathrm{C}, \mathrm{B}$, and $\mathrm{A}$ in the mandible (all $\mathrm{P}<.05$ ) (Figs. 5 and 6). Cortical bone thickness and density were significantly greater at site $\mathrm{B}$ than at site $\mathrm{C}$, while cortical bone density was significantly greater at site $\mathrm{A}$ than at site $\mathrm{C}$ (both $\mathrm{P}<.05$ ) (Figs. 5 and 6). However, there were no statistical differences in cortical bone thickness and density between sites A and B (P > .05) (Figs. 5 and 6). 
WANG, S.; BING, L. \& PARK, H. S. Optimal microimplant sites in the mandibular retromolar area: Mesh analysis of cortical bone thickness and density in CBCT images. Int. J. Morphol., 39(3):907-914, 2021.

Table V Multiple comparisons of cortical bone density in retromolar area.

\begin{tabular}{|c|c|c|c|c|}
\hline \multirow[t]{2}{*}{ (I) $\mathrm{z}$} & \multirow[t]{2}{*}{ (J) $\mathrm{z}$} & \multicolumn{3}{|c|}{ Density (HU) } \\
\hline & & Mean Difference (I-J) & Std. Error & Sig. ${ }^{\mathrm{c}}$ \\
\hline \multirow[t]{24}{*}{$\mathrm{S} 5 \mathrm{C} 1$} & $\mathrm{~S} 1 \mathrm{C} 1$ & $276.857 *$ & 18.899 & $<.0001$ \\
\hline & $\mathrm{S} 1 \mathrm{C} 2$ & $337.163 *$ & 18.956 & $<.0001$ \\
\hline & $\mathrm{S} 1 \mathrm{C} 3$ & $376.531 *$ & 20.620 & $<.0001$ \\
\hline & $\mathrm{S} 1 \mathrm{C} 4$ & $383.408 *$ & 20.196 & $<.0001$ \\
\hline & S1C5 & $385.224 *$ & 19.918 & $<.0001$ \\
\hline & $\mathrm{S} 2 \mathrm{C} 1$ & $221.327^{*}$ & 16.931 & $<.0001$ \\
\hline & $\mathrm{S} 2 \mathrm{C} 2$ & $205.980 *$ & 62.355 & 0.002 \\
\hline & $\mathrm{S} 2 \mathrm{C} 3$ & $285.633^{*}$ & 16.938 & $<.0001$ \\
\hline & $\mathrm{S} 2 \mathrm{C} 4$ & $283.041 *$ & 20.212 & $<.0001$ \\
\hline & $\mathrm{S} 2 \mathrm{C} 5$ & $294.898^{*}$ & 21.361 & $<.0001$ \\
\hline & $\mathrm{S} 3 \mathrm{C} 1$ & $128.939 *$ & 12.215 & $<.0001$ \\
\hline & $\mathrm{S} 3 \mathrm{C} 2$ & $186.837 *$ & 12.951 & $<.0001$ \\
\hline & $\mathrm{S} 3 \mathrm{C} 3$ & $197.265^{*}$ & 12.180 & $<.0001$ \\
\hline & $\mathrm{S} 3 \mathrm{C} 4$ & $203.878^{*}$ & 17.372 & $<.0001$ \\
\hline & $\mathrm{S} 3 \mathrm{C} 5$ & $234.592 *$ & 18.303 & $<.0001$ \\
\hline & $\mathrm{S} 4 \mathrm{C} 1$ & $47.857^{*}$ & 9.951 & $<.0001$ \\
\hline & $\mathrm{S} 4 \mathrm{C} 2$ & $98.367 *$ & 12.216 & $<.0001$ \\
\hline & $\mathrm{S} 4 \mathrm{C} 3$ & $137.592 *$ & 13.131 & $<.0001$ \\
\hline & $\mathrm{S} 4 \mathrm{C} 4$ & $168.592 *$ & 13.965 & $<.0001$ \\
\hline & $\mathrm{S} 4 \mathrm{C} 5$ & $194.796 *$ & 13.424 & $<.0001$ \\
\hline & $\mathrm{S} 5 \mathrm{C} 2$ & $39.694 *$ & 5.220 & $<.0001$ \\
\hline & $\mathrm{S} 5 \mathrm{C} 3$ & $80.408^{*}$ & 8.563 & $<.0001$ \\
\hline & S5C4 & $122.122 *$ & 10.626 & $<.0001$ \\
\hline & $\mathrm{S} 5 \mathrm{C} 5$ & $145.755^{*}$ & 12.029 & $<.0001$ \\
\hline
\end{tabular}

Based on estimated marginal means. *. P $<.05$ for mean difference. c. Adjustment for multiple comparisons: Least Significant Difference test (equivalent to no adjustments).

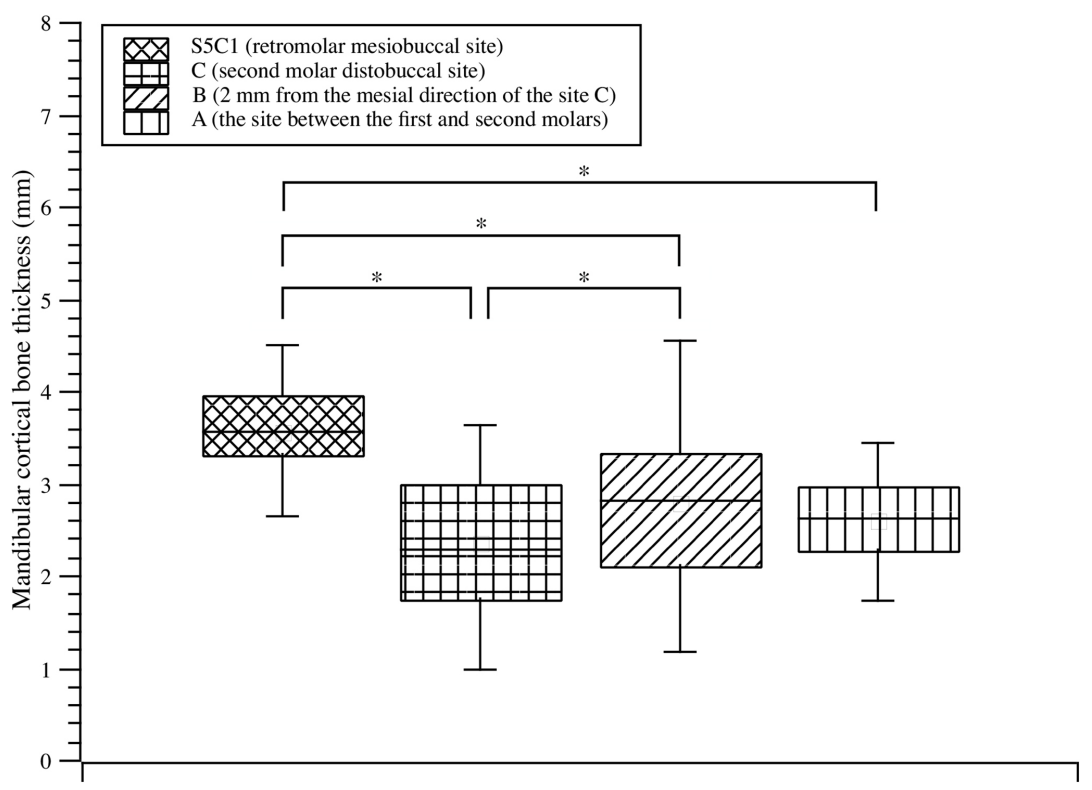

Fig. 5 Comparison of thicknesses of $\mathrm{S} 5 \mathrm{C} 1, \mathrm{~A}, \mathrm{~B}$ and $\mathrm{C}$ sites in the mandible $(* \mathrm{P}<$ $.05)$.

\section{DISCUSSION}

The mandibular retromolar area is increasingly used as a microimplant site for distal uprighting of mesially tipped molars (Park et al., 2004) and retraction of mandibular dentition (Poletti et al.). With respect to bone density measurement, the $\mathrm{X}$-ray absorption of bone exhibits a constant ratio to calcium in terms of bone volume and this is influenced by the radiopaqueness quality of roentgenograms (Buck \& Wheeler, 1969). Hounsfield (1995) invented the first CT scanner, and Misch (2008) proposed that Hounsfield units (HU) could be used to express bone density. Furthermore, Park et al. (2008) evaluated bone density at nearly all orthodontic microimplant sites in adult patients, and Choi et al. (2009) concluded that density values were higher in the mandible than in the maxilla. Regarding the mandibular retromolar area, Buck \& Wheeler concluded that retromolar and alveolar bone density did not significantly differ. There have been, however, not enough study evaluating the differences in bone thickness and density according to sites. This study quantitatively measured cortical bone thickness and density in the retromolar area on a mesh in CBCT images. Previously, Park et al. (2008) suggested that the success rate of microimplants could be affected by bone density and thickness. To improve the success rate of microimplants in the mandibular retromolar area, we aimed to identify optimal microimplant sites in this area.

Our results showed that cortical bone thickness in the retromolar area was $2.35 \pm$ $0.76 \mathrm{~mm}$. It was consistent with a previous study stating that the retromolar area had sufficient cortical bone thickness (1.96 to $2.06 \mathrm{~mm}$ ) (Park \& Cho, 2009), although it was thinner than in our study. The density of the retromolar area was $530.49 \pm 188.83$ $\mathrm{HU}$; these results were consistent with the findings of Misch, who evaluated the D3 $(350-850 \mathrm{HU})$ in the posterior mandible and maxilla. Thus, the mandibular retromolar area is suitable for microimplant placement. 
WANG, S.; BING, L. \& PARK, H. S. Optimal microimplant sites in the mandibular retromolar area: Mesh analysis of cortical bone thickness and density in CBCT images. Int. J. Morphol., 39(3):907-914, 2021

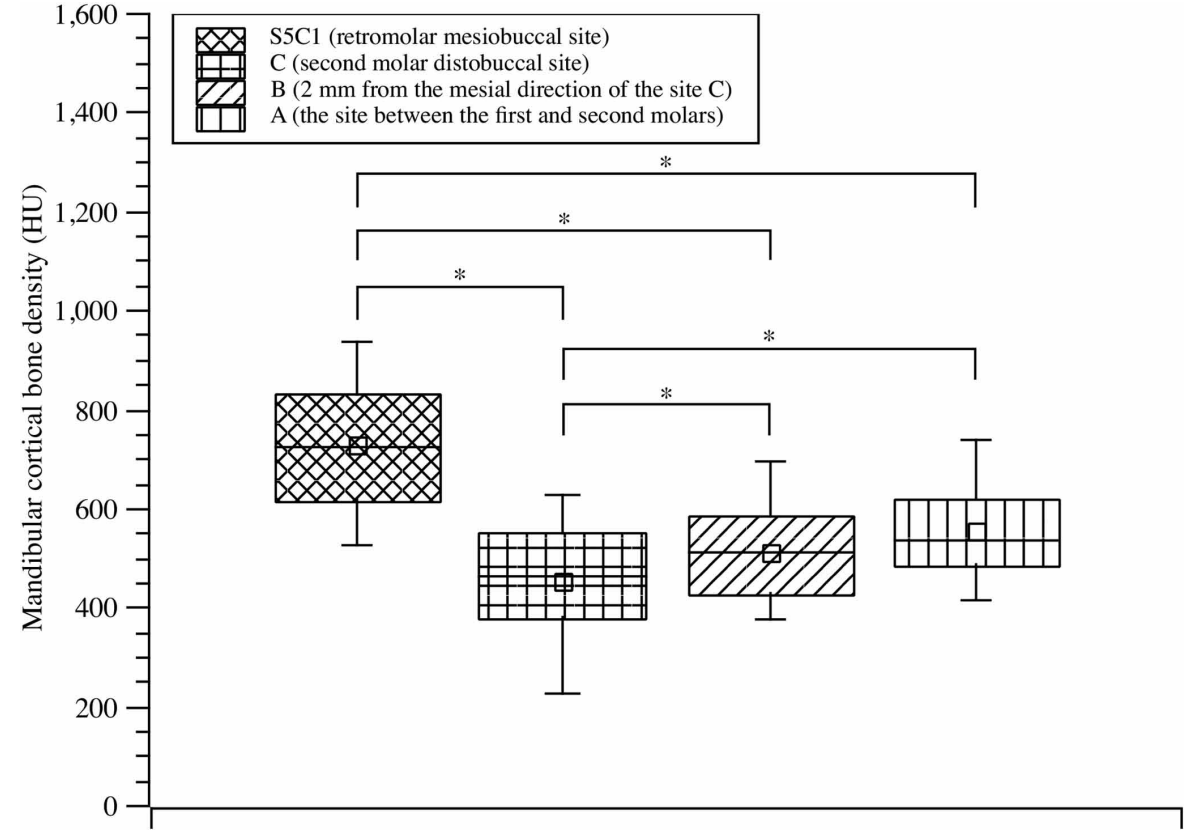

Fig. 6 Comparison of densities of S5C1, A, B and C sites in the mandible $(* \mathrm{P}<.05)$.

Notably, microimplant placement in the retromolar area may cause soft tissue inflammation and patient discomfort (Park, 2015). Moreover, the heads of microimplants can be covered by soft tissue and involve occasional occlusal contact with upper teeth; the need for a ligature wire extension may be evident (Park, 2015). Therefore, the mesial and buccal sites might be suggested for microimplant placement for distalization. However, if an extrusive force is needed during distalization (e.g., during Class III camouflage treatment), the distal retromolar area might be a suitable option. Otherwise, the retromolar area may be unsuitable, despite the presence of greater bone thickness and

The results of Spearman correlation and binary logistic regression analyses showed that the presence of a third molar was significantly positively correlated with retromolar cortical bone thickness; moreover, the cortical bone thickness of the retromolar area was greater in the presence than in the absence of a third molar. The reduced cortical bone thickness in the retromolar area of the second molar might be caused by third molar extraction (Park, 2015), although we excluded images from patients who had undergone extraction within the previous 6 months. To facilitate the success of microimplant placement, orthodontists should carefully monitor the thickness of retromolar cortical bone in patients who have undergone third molar extraction, during implantation of microimplants in the mandibular retromolar area.

For distalization of mandibular dentition, the distobuccal bone of the second molar or the retromolar area can be used for microimplant placement (Park, 2015). The LSD and one-way ANOVA assessments revealed that site S5C1 had the greatest cortical bone thickness and density among 25 sites in the retromolar area; it exhibited greater thickness and density, compared with the distobuccal bone of the second molar and the site between the first and second molars. Marquezan et al. (2014) concluded that microimplant stability has a positive association with cortical bone thickness. Thus, microimplant placement at the mesiobuccal site (S5C1) in the retromolar area can be recommended for the distalization of the mandibular dentition. density, compared with the distobuccal bone to the second molar. Especially in patients who exhibit hyperdivergence, mandibular posterior teeth should be intruded during distalization to minimize mandibular plane angle opening or the increase of the lower facial height. In these instances, to achieve intrusive force by positioning the head of microimplant down to brackets level, microimplants need to be placed in distobuccal bone to the second molar or in the bone between the first and second molars (Park, 2015). Because bone in the mandibular posterior and retromolar areas exhibits sufficient thickness and density, the placement site can be determined by the force direction suitable for treatment (Park, 2015). Our results showed that cortical bone thickness and density were higher at site $\mathrm{B}$ (i.e., $2 \mathrm{~mm}$ mesial to site $\mathrm{C}$ ) than at site $\mathrm{C}$ (i.e., $2 \mathrm{~mm}$ distal and buccal to the second molar); there were no significant differences in cortical bone thickness and density between sites B and A (i.e., site between the first and second molars). Thus, microimplants can be placed into site B for distalization of the dentition and into site $\mathrm{A}$ for distalization of dentition with intrusion of molars.

When placing the microimplants into mesio-buccal side of the mandibular retromolar or site $\mathrm{A}$ and $\mathrm{B}$, clinicians need to remember the higher possibility of microimplant fracture during surgery, as well as the possibility of occlusal contact between microimplants and maxillary molars (Park, 2015). For distal uprighting of a mesially tipped second molar, microimplants need to be placed distally to provide space for uprighting. The buccal side might be preferable 
to the lingual side(Park et al., 2004), because mesially tipped second molars often exhibit lingual tipping; thus, distal and buccal forces are needed to achieve an upright orientation.

Previously, Papageorgiou et al. (2012) concluded that the mean microimplant failure rate in the mandibular retromolar area was $13.5 \%$; Park (2003) reported a low success rate and Azeem et al. (2019) reported a retromolar microimplant failure rate of $23.2 \%$. These low success rates might have been caused by excessive heat during drilling in retromolar cortical bone, as well as inflammation related to movement and excess oral mucosa (Park, 2003). Therefore, to increase the success rate and reduce heat generation, we recommend the use of long microimplants and placement with a no-drill method in the mandibular retromolar area.

Our study provides clinicians with accurate data regarding cortical bone thickness and density in the retromolar area, as well as information regarding optimal microimplant sites, which may improve the success rate of microimplant placement. A notable limitation of our study was that the sample size is small and the possible difference according to age and sex was not evaluated. Further studies are required to evaluate the effects of these factors on cortical bone thickness and density.

\section{CONCLUSIONS}

The cortical bone thickness and density increased from the lingual to buccal sides, as well as from the distal to mesial sides. The microimplant site with the greatest thickness and density was S5C1 (mesial buccal site) among 25 sites in the mandibular retromolar area; it exhibited greater thickness and density, compared with the distobuccal bone of the second molar and the site between the first and second molars. We recommend to place microimplantinto distobuccal sites in the retromolar for distal uprighting of mesially tipped molars, and into mesiobuccal site in the retromolar area (S5C1) or site B and site $\mathrm{A}$ for distalization of the mandibular dentition.

WANG, S.; BING, L. \& PARK, H. S. Microimplantsites óptimos en el área retromolar mandibular: análisis de malla del grosor y densidad del hueso cortical en imágenes CBCT. Int. J. Morphol., 39(3):907-914, 2021.

RESUMEN: Este estudio se realizó para identificar los sitios óptimos de microimplantes en el área retromolar mandibular mediante la medición y el análisis del grosor y la densidad del hueso cortical. Se seleccionaron 49 registros de tomografía computarizada de haz cónico de 173 pacientes. Se utilizó el software Invivo 5.2 para medir el grosor y la densidad de 25 sitios en una malla en el área retromolar mandibular. Se realizaron análisis de correlación de Pearson, correlación de Spearman y regresión logística binaria para explorar las correlaciones entre las mediciones retromolares y las características del paciente. La prueba de LSD se utilizó para identificar los sitios óptimos de microimplantes en esta área. Se utilizó ANOVA unidireccional, con prueba SNK post hoc, para comparar los sitios óptimos de microimplante entre el área retromolar, el hueso distobucal del segundo molar y una ubicación entre el primer y el segundo molar. El grosor y la densidad medios del hueso cortical retromolar mandibular fueron $2,35 \pm 0,76 \mathrm{~mm}$ y $530,49 \pm 188,83 \mathrm{HU}$, respectivamente. En el área retromolar mandibular, el grosor y la densidad del hueso cortical aumentaron desde el lado lingual al bucal y desde el distal al mesial. Entre los 25 sitios, S5C1 se determinó el mayor espesor y densidad; presentó mayor grosor y densidad, en comparación con el hueso distobucal del segundo molar y el sitio entre el primero y el segundo molar. Para rectificación distal de molares con punta mesial, recomendamos la colocación de microimplantes en el sitio retromolar bucal; para la distalización de la dentición mandibular, recomendamos la colocación de microimplantes en el sitio retromolar mesiobucal (S5C1) o 2 mm desde la dirección mesial del sitio distobucal del segundo molar (B).

PALABRAS ClAVE: Retromolar; Sitios de microimplantes; Grosor; Densidad; Análisis de mallas.

\section{REFERENCES}

Aljhani, A. \& Zawawi, K. H. The use of mini-implants in en masse retraction for the treatment of bimaxillary dentoalveolar protrusion. Saudi Dent. J., 22(1):35-9, 2010.

Azeem, M.; Saleem, M. M.; Liaquat, A.; Haq, A. U.; Hamid, W. U. \& Masood, M. Failure rates of mini-implants inserted in the retromolar area. Int. Orthod., 17(1):53-9, 2019.

Bechtold, T. E.; Kim, J. W.; Choi, T. H.; Park, Y. C.\& Lee, K. J. Distalization pattern of the maxillary arch depending on the number of orthodontic miniscrews. Angle Orthod., 83(2):266-73, 2013.

Buck, D. L. \& Wheeler, P. W. A density comparison of human alveolar and retromolar bone. Angle Orthod., 39(2):133-6, 1969.

Choi, J. H.; Park, C. H.; Yi, S. W.; Lim, H. J. \& Hwang, H. S. Bone density measurement in interdental areas with simulated placement of orthodontic miniscrew implants. Am. J. Orthod. Dentofac. Orthop., 136(6):766.e1-12; discussion 766-7, 2009.

Chung, K. R.; Kim, S. H.; Choo, H.; Kook, Y. A. \& Cope, J. B. Distalization of the mandibular dentition with mini-implants to correct a Class III malocclusion with a midline deviation. Am. J. Orthod. Dentofac. Orthop., 137(1):135-46, 2010.

Dahlberg, G. Statistical Methods for Medical and Biological Students. Indian Med. Gaz., 75(10):638, 1940.

Farnsworth, D.; Rossouw, P. E.; Ceen, R. F. \& Buschang, P. H. Cortical bone thickness at common miniscrew implant placement sites. Am. J. Orthod. Dentofac. Orthop., 139(4):495-503, 2011.

Horner, K. A.; Behrents, R. G.; Kim, K. B. \& Buschangd, P. H. Cortical bone and ridge thickness of hyperdivergent and hypodivergent adults. Am. J. Orthod. Dentofac. Orthop., 142(2):170-8, 2012. 
Hounsfield, G. N. Computerized transverse axial scanning (tomography): Part I. Description of system. 1973. Br. J. Radiol., 68(815):H166-72, 1995.

Marquezan, M.; Mattos, C. T.; Sant'Anna, E. F.; Souza, M. M. G. \& Maia, L. C. Does cortical thickness influence the primary stability of miniscrews?: A systematic review and meta-analysis. Angle Orthod., 84(6):1093-103, 2014.

Misch, C. E. Diagnostic Imaging Techniques. In: Misch, C. E. (Ed.). Contemporary Implant Dentistry. 3rd ed. St. Louis, CV Mosby Company, 2008

Ozdemir, F.; Tozlu, M. \& Germec-Cakan, D. Cortical bone thickness of the alveolar process measured with cone-beam computed tomography in patients with different facial types. Am. J. Orthod. Dentofac. Orthop., 143(2):190-6, 2013

Papageorgiou, S. N.; Zogakis, I. P. \& Papadopoulos, M. A. Failure rates and associated risk factors of orthodontic miniscrew implants: a metaanalysis. Am. J. Orthod. Dentofac. Orthop., 142(5):577-595.e7., 2012.

Park, H. S. \& Oh, Y. H. Forced eruption of a labially impacted canine using joined microimplants. J. Clin. Orthod., 44(2):108-13, 2010.

Park, H. S. Clinical study on success rate of microscrew implants for orthodontic anchorage. Korean J. Orthod., 33(3):151-6, 2003.

Park, H. S. Microimplants in Orthodontic Treatment. Daegu, Dentos Co. Ltd., 2015.

Park, H. S.; Kim, J. Y. \& Kwon, T. G.Treatment of a Class II deepbite with microimplant anchorage. Am. J. Orthod. Dentofac. Orthop., 139(3):397406, 2011.

Park, H. S.; Kwon, O. W. \& Sung, J. H. Uprighting second molars with micro-implant anchorage. J. Clin. Orthod., 38(2):100-3, 2004.

Park, H. S.; Lee, Y. J.; Jeong, S. H. \& Kwon, T. G. Density of the alveolar and basal bones of the maxilla and the mandible. Am. J. Orthod. Dentofac. Orthop., 133(1):30-7, 2008.

Park, J. \& Cho, H. J. Three-dimensional evaluation of interradicular spaces and cortical bone thickness for the placement and initial stability of microimplants in adults. Am. J. Orthod. Dentofac. Orthop., 136(3):314.e1-12; discussion 314-5, 2009.

Poletti, L.; Silvera, A. A. \& Ghislanzoni, L. T. H. Dentoalveolar class III treatment using retromolarminiscrew anchorage. Prog. Orthod., 14(1):7, 2013.

Upadhyay, M.; Yadav, S.; Nagaraj, K. \& Patil, S. Treatment effects of miniimplants for en-masse retraction of anterior teeth in bialveolar dental protrusion patients: A randomized controlled trial. Am. J. Orthod. Dentofac. Orthop., 134(1):18-29.e1, 2008.

Yao, C. C. J.; Wu, C. B.; Wu, H. Y.; Kok, S. H.; Chang, H. F. F. \& Chen, Y. J. Intrusion of the overerupted upper left first and second molars by mini-implants with partial-fixed orthodontic appliances: A case report. Angle Orthod., 74(4):550-7, 2004.

\author{
Corresponding author: \\ Hyo-Sang Park \\ Department of Orthodontics \\ School of Dentistry \\ Kyungpook National University \\ 188-2, Samduk 2-Ga, Jung-Gu \\ Daegu \\ KOREA
}

\section{E-mail:parkhs@knu.ac.kr}

Received: 16-03-2021

Accepted: 09-04-2021 